$\underline{\text { Technical Note }}$

\title{
An Estimate of Energy Use in Laboratories, Cleanrooms, and Data Centers in New York
}

\author{
Paul Mathew, Ph.D. \\ Staff Scientist \\ Lawrence Berkeley National Laboratory

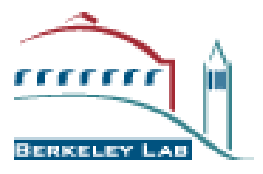

Prepared for:

Susan Andrews

Program Manager

New York State Energy Research and Development Authority 


\section{Disclaimer}

This document was prepared as an account of work sponsored by the United States Government. While this document is believed to contain correct information, neither the United States Government nor any agency thereof, nor The Regents of the University of California, nor any of their employees, makes any warranty, express or implied, or assumes any legal responsibility for the accuracy, completeness, or usefulness of any information, apparatus, product, or process disclosed, or represents that its use would not infringe privately owned rights. Reference herein to any specific commercial product, process, or service by its trade name, trademark, manufacturer, or otherwise, does not necessarily constitute or imply its endorsement, recommendation, or favoring by the United States Government or any agency thereof, or The Regents of the University of California. The views and opinions of authors expressed herein do not necessarily state or reflect those of the United States Government or any agency thereof or The Regents of the University of California.

\section{Acknowledgements}

This work was supported by the New York State Energy Research and Development Authority (NYSERDA), under NYSERDA Buyer's Order No. 6806-EA-01, and by the Assistant Secretary for Energy Efficiency and Renewable Energy, Building Technologies Program, of the U.S. Department of Energy under Contract No. DE-AC02-05CH11231. 


\section{An Estimate of Energy Use in Laboratories, Cleanrooms, and Data Centers in New York}

\section{Executive Summary}

Laboratories, cleanrooms and data centers are very energy-intensive. For example, laboratories are typically three to eight times as energy intensive as a typical office building, and a data center may be as much as 20-50 times as energy intensive as a typical office building.

This technical note presents an estimate of the total energy use in laboratories, cleanrooms and data centers in New York. There is generally very limited data on energy use in the high tech sector, both at the national and state level. Since it was beyond the scope of this project to develop primary data through surveys, the analysis relied primarily on the use of proxy indicators and extrapolation from national data where available. The results for each building type are summarized below in table E-1 and figure E-1.

\begin{tabular}{|l|r|r|r|rr|}
\hline & $\begin{array}{c}\text { Electricity } \\
\text { (GWh) }\end{array}$ & \multicolumn{1}{|c|}{$\begin{array}{c}\text { Fuel } \\
\text { (tBTU) }\end{array}$} & \multicolumn{2}{|c|}{$\begin{array}{c}\text { Site Energy } \\
\text { (tBTU) }\end{array}$} & \multicolumn{2}{c|}{$\begin{array}{c}\text { Energy Costs } \\
\text { (Million \$) }\end{array}$} \\
\hline Laboratories & 3,453 & 21 & 33 & $\$$ & 730 \\
\hline Clean rooms & 696 & 3 & 5 & $\$$ & 126 \\
\hline Data centers & 4,557 & - & 16 & $\$$ & 620 \\
\hline Total & $\mathbf{8 , 7 0 6}$ & $\mathbf{2 4}$ & $\mathbf{5 4}$ & $\mathbf{\$}$ & $\mathbf{1 , 4 7 6}$ \\
\hline $\begin{array}{l}\text { Hightech vs. } \\
\text { all commercial (\%) }\end{array}$ & $11.2 \%$ & $5.6 \%$ & $7.7 \%$ & $8.7 \%$ \\
\hline
\end{tabular}

Table E-1. Summary of annual electricity, fuel and site energy use and expenditures for laboratories, cleanrooms, and data centers in New York.

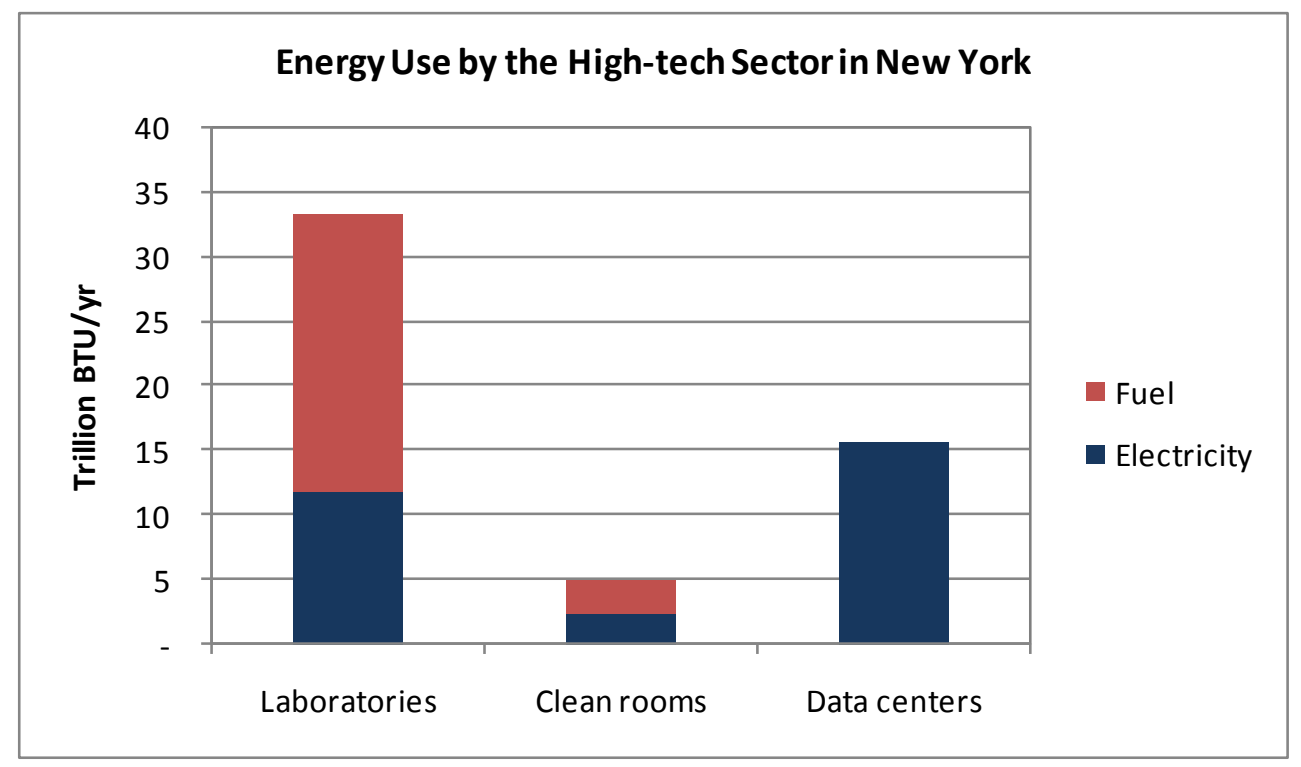

Figure E-1. Energy use by laboratories, cleanrooms, and data centers in New York. 


\section{Introduction}

Laboratories, cleanrooms and data centers are very energy-intensive. For example, laboratories are typically three to eight times as energy intensive as a typical office building, and a data center may be as much as 20-50 times as energy intensive as a typical office building.

This technical note presents an estimate of the total energy use and savings potential for laboratories, cleanrooms and data centers in New York. It was prepared as part of a research project entitled "Self-benchmarking for the High Tech Sector in New York", sponsored by the New York State Energy Research and Development Authority (NYSERDA) and performed by Law rence Berkeley National Laboratory (LBNL).

There is generally very limited data on energy use in the high tech sector, both at the national and state level. High tech buildings are typically not tracked in national and regional surveys of commercial building energy use. Furthermore, these spaces are often part of other building types (e.g. data centers within office buildings, cleanrooms within manufacturing facilities). A data search yielded virtually no public domain data specific to New York. Since it was beyond the scope of this project to develop primary data through surveys, the analysis relied primarily on the use of proxy indicators and extrapolation from national data where available. In the remainder of this document, we present the available data sources, analysis approach and results for each building type.

\section{Laboratories}

\subsection{Data Sources}

The Commercial Buildings Energy Consumption Survey (CBECS) is a national sample survey that collects information on the stock of U.S. commercial buildings, their energy-related building characteristics, and their energy consumption and expenditures [EIA 2003]. Commercial buildings include all buildings in which at least half of the floor space is used for a purpose that is not residential, industrial, or agricultural. CBECS is developed by the Energy Information Agency (EIA), an agency of the U.S. Department of Energy. Building types in CBECS are classified in terms of "principal building activity" (PBA). The CBECS sample contains 43 buildings in which the PBA is "laboratory". For each of these buildings, the geographical location is described in terms of census region and census division (see figure 1). New York falls into the Northeast region and Mid-Atlantic division. Buildings are not identifiable by state. Of the 43 laboratory buildings in CBECS, 14 are in the North-east region, of which five are in the mid-Atlantic division (New York, New Jersey and Pennsylvania).

The Labs21 benchmarking database [Labs21 2008], sponsored by the national Laboratories for the $21^{\text {st }}$ Century Program has over 100 laboratory buildings. While this is larger than the number of laboratory buildings in CBECS, this database is not designed as a national statistical sample, and therefore is not well suited for sector-level analysis.

In addition to the above data sources, NYSERDA has compiled a report on New York state energy profiles (hereafter referred to as NYSEP) from 1992-2006 [NYSERDA 2008]. This report provides data on energy production and use, sources of energy supply, fuel prices, and total energy expenditures, by sector and end-use. Comparisons of data across states and to the U.S. average are also provided for selected indicators. The report breaks out energy use for the commercial sector as a whole, but not for specific building types within that sector. 


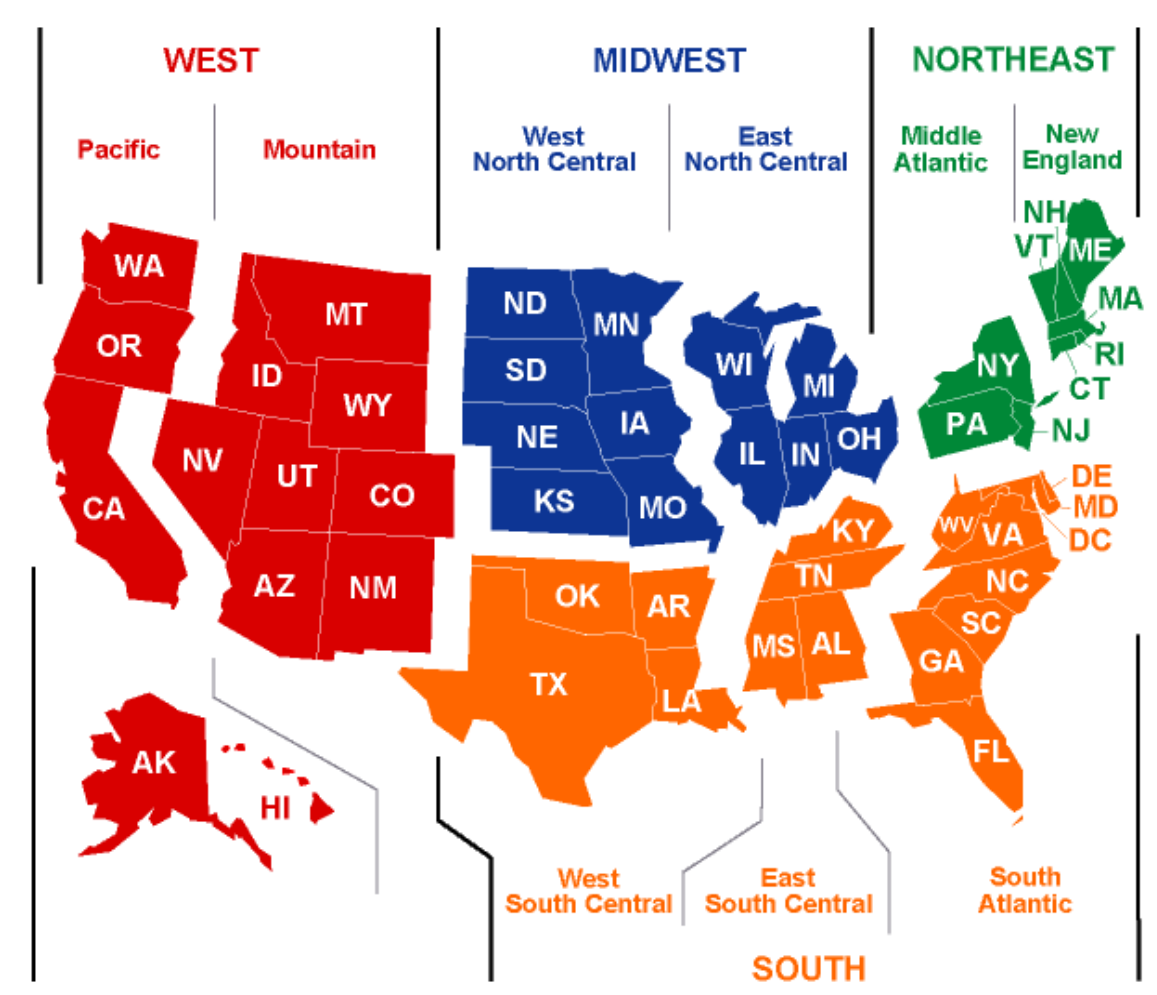

Figure 1. U.S. census regions and divisions used in CBECS database.

(source: $h t t p: / / w w w . e i a . d o e . g o v / e m e u / c b e c s / c e n s u s \_m a p s . h t m l$ )

\subsection{Analysis}

Given the above data sources, the following approach was used to estimate the energy use and costs for the laboratory sector in New York:

1. CBECS data was used to estimate the laboratory sector energy use as a percentage of total energy use, for the North-east census region. (The number of data points for the mid-Atlantic division is too small for a meaningful analysis - only 5 lab buildings, as noted earlier). The result is $4.8 \%$. As a point of reference, the value for the whole US is $3.1 \%$ i.e. the laboratory sector as a percentage of all commercial buildings is slightly larger in the north-east than it is for the whole US - which is consistent with anecdotal evidence from the market. Percentage values were also calculated for site electricity and fuel.

2. The laboratory sector energy use percentages were applied to the New York commercial sector energy use data - electricity, fuel, site energy - from the NYSEP report.

3. Total costs for electricity and fuel were calculated using average per-unit costs from the NYSEP report.

Table 1 summarizes the data items and calculation of the estimate of energy use and expenditures for laboratories in New York. The total electricity use and expenditures are 3,453 GWh and $\$ 470$ million. The total fuel use and expenditures are 21 trillion BTUs and $\$ 260$ million. The total site energy use and expenditures are 33 trillion BTUs and $\$ 730$ million. 


\begin{tabular}{|c|c|c|c|}
\hline ID & Data Item & Value & Source \\
\hline A & North-east - All commercial - Site energy (tBTU) & 1,397 & CBECS \\
\hline $\mathrm{B}$ & North-east - Labs - Site energy (tBTU) & 67 & CBECS \\
\hline $\mathrm{C}$ & North-east - Labs vs. All (\% site energy) & $4.8 \%$ & $\mathrm{~B} / \mathrm{A}$ \\
\hline $\mathrm{D}$ & North-east - All commercial - Electricity (tBTU) & 587 & CBECS \\
\hline $\mathrm{E}$ & North-east - Labs - Electricity (tBTU) & 26 & CBECS \\
\hline $\mathrm{F}$ & North-east - Labs vs. All (\% electricity) & $4.5 \%$ & $E / D$ \\
\hline $\mathrm{G}$ & North-east - All commercial - Fuel (tBTU) & 810 & CBECS \\
\hline $\mathrm{H}$ & North-east - Labs - Fuel (tBTU) & 40 & CBECS \\
\hline $\mathrm{I}$ & North-east - Labs vs. All (\% fuel) & $5.0 \%$ & $\mathrm{H} / \mathrm{G}$ \\
\hline $\mathrm{J}$ & NY - All commercial - Site energy (tBTU) & 694 & NYSEP \\
\hline $\mathrm{K}$ & NY - All commercial - Electricity (GWh) & 77,419 & NYSEP \\
\hline $\mathrm{L}$ & NY - All commercial - Fuel (tBTU) & 430 & NYSEP \\
\hline $\mathrm{M}$ & NY - Labs - Site energy (tBTU) & 33 & $J^{*} \mathrm{C}$ \\
\hline $\mathrm{N}$ & NY - Labs - Electricity (GWh) & 3,453 & $\mathrm{~K}^{*} \mathrm{~F}$ \\
\hline $\mathrm{O}$ & NY - Labs - Fuel (tBTU) & 21 & $L^{*} I$ \\
\hline $\mathrm{P}$ & NY - Average commercial electricity cost $(\$ / k W h)$ & $\$ 0.136$ & NYSEP \\
\hline $\mathrm{Q}$ & NY - Average commercial natural gas cost (\$/MCF) & $\$ 12.10$ & NYSEP \\
\hline $\mathrm{R}$ & NY - Labs - Electricty expenditures (Million \$) & 470 & $\mathrm{~K}^{*} \mathrm{P}$ \\
\hline $\mathrm{S}$ & NY - Labs - Fuel expenditures (Million \$) & 260 & $\mathrm{O}^{*} \mathrm{Q}$ \\
\hline $\mathrm{T}$ & NY - Labs - Total energy expenditures (Million \$) & 730 & $\mathrm{R}+\mathrm{S}$ \\
\hline
\end{tabular}

Notes:

1. Site energy may not equal sum of electricity and fuel due to rounding.

2. Fuel expenditures were based on price of natural gas, although fuels m ay include other fuel types.

Table 1. Estimate for laboratory sector energy use in New York.

\section{Cleanrooms}

\subsection{Data Sources}

The McIlvane company surveys and tracks cleanroom construction in the United States and has commercially available reports on cleanroom floor space and characteristics. LBNL procured cleanroom data for New York, which included total area by cleanroom class and industry type. Data were provided for 2003-2010 (data for 2007-2010 were predictions). Tables 3 and 4, and figures 2, 3 and 4 summarize the data from the McIlvane report. The report did not have energy use data.

\begin{tabular}{|l|c|c|c|c|c|c|c|c|}
\hline \multicolumn{10}{|c|}{ Cleanroom Space for New York State - Total Space (million sq. ft.) } \\
\hline \hline & $\mathbf{2 0 0 3}$ & $\mathbf{2 0 0 4}$ & $\mathbf{2 0 0 5}$ & $\mathbf{2 0 0 6}$ & $\mathbf{2 0 0 7}$ & $\mathbf{2 0 0 8}$ & $\mathbf{2 0 0 9}$ & $\mathbf{2 0 1 0}$ \\
\hline Cleanroom Suppliers & 0.026 & 0.026 & 0.026 & 0.026 & 0.026 & 0.027 & 0.027 & 0.027 \\
Food & 0.044 & 0.045 & 0.046 & 0.047 & 0.048 & 0.049 & 0.051 & 0.052 \\
Hospital & 0.215 & 0.216 & 0.217 & 0.217 & 0.218 & 0.219 & 0.220 & 0.221 \\
Other Electronics & 0.147 & 0.160 & 0.173 & 0.188 & 0.203 & 0.220 & 0.239 & 0.259 \\
Other Industries & 0.319 & 0.320 & 0.321 & 0.322 & 0.324 & 0.325 & 0.326 & 0.328 \\
Pharmaceutical & 0.564 & 0.608 & 0.655 & 0.705 & 0.759 & 0.818 & 0.881 & 0.949 \\
Semiconductor & 0.302 & 0.332 & 0.364 & 0.400 & 0.439 & 0.482 & 0.529 & 0.581 \\
\hline TOTAL & $\mathbf{1 . 6 1 7}$ & $\mathbf{1 . 7 0 6}$ & $\mathbf{1 . 8 0 2}$ & $\mathbf{1 . 9 0 6}$ & $\mathbf{2 . 0 1 8}$ & $\mathbf{2 . 1 4 0}$ & $\mathbf{2 . 2 7 3}$ & $\mathbf{2 . 4 1 6}$ \\
\hline
\end{tabular}

Table 3. Cleanroom space in New York, by Industry type. Data source: McIlvane company. 


\begin{tabular}{|l|c|c|c|c|c|c|c|c|}
\hline \multicolumn{7}{|c|}{ Cleanroom Space for New York State - Total Space (million sq. ft.) } \\
\hline \hline & $\mathbf{2 0 0 3}$ & $\mathbf{2 0 0 4}$ & $\mathbf{2 0 0 5}$ & $\mathbf{2 0 0 6}$ & $\mathbf{2 0 0 7}$ & $\mathbf{2 0 0 8}$ & $\mathbf{2 0 0 9}$ & $\mathbf{2 0 1 0}$ \\
\hline Class 1-10 & 0.188 & 0.204 & 0.222 & 0.242 & 0.263 & 0.286 & 0.312 & 0.340 \\
Class 100 & 0.250 & 0.265 & 0.282 & 0.300 & 0.319 & 0.340 & 0.362 & 0.387 \\
Class 1000 & 0.277 & 0.295 & 0.315 & 0.337 & 0.360 & 0.386 & 0.413 & 0.443 \\
Class 10,000 & 0.284 & 0.299 & 0.315 & 0.332 & 0.351 & 0.371 & 0.393 & 0.417 \\
Class 100,000 & 0.618 & 0.642 & 0.668 & 0.695 & 0.725 & 0.758 & 0.792 & 0.830 \\
\hline Total & $\mathbf{1 . 6 1 7}$ & $\mathbf{1 . 7 0 6}$ & $\mathbf{1 . 8 0 2}$ & $\mathbf{1 . 9 0 6}$ & $\mathbf{2 . 0 1 8}$ & $\mathbf{2 . 1 4 0}$ & $\mathbf{2 . 2 7 3}$ & $\mathbf{2 . 4 1 6}$ \\
\hline
\end{tabular}

Table 4. Cleanroom space in New York, by cleanroom class. Data source: McIlvane company.

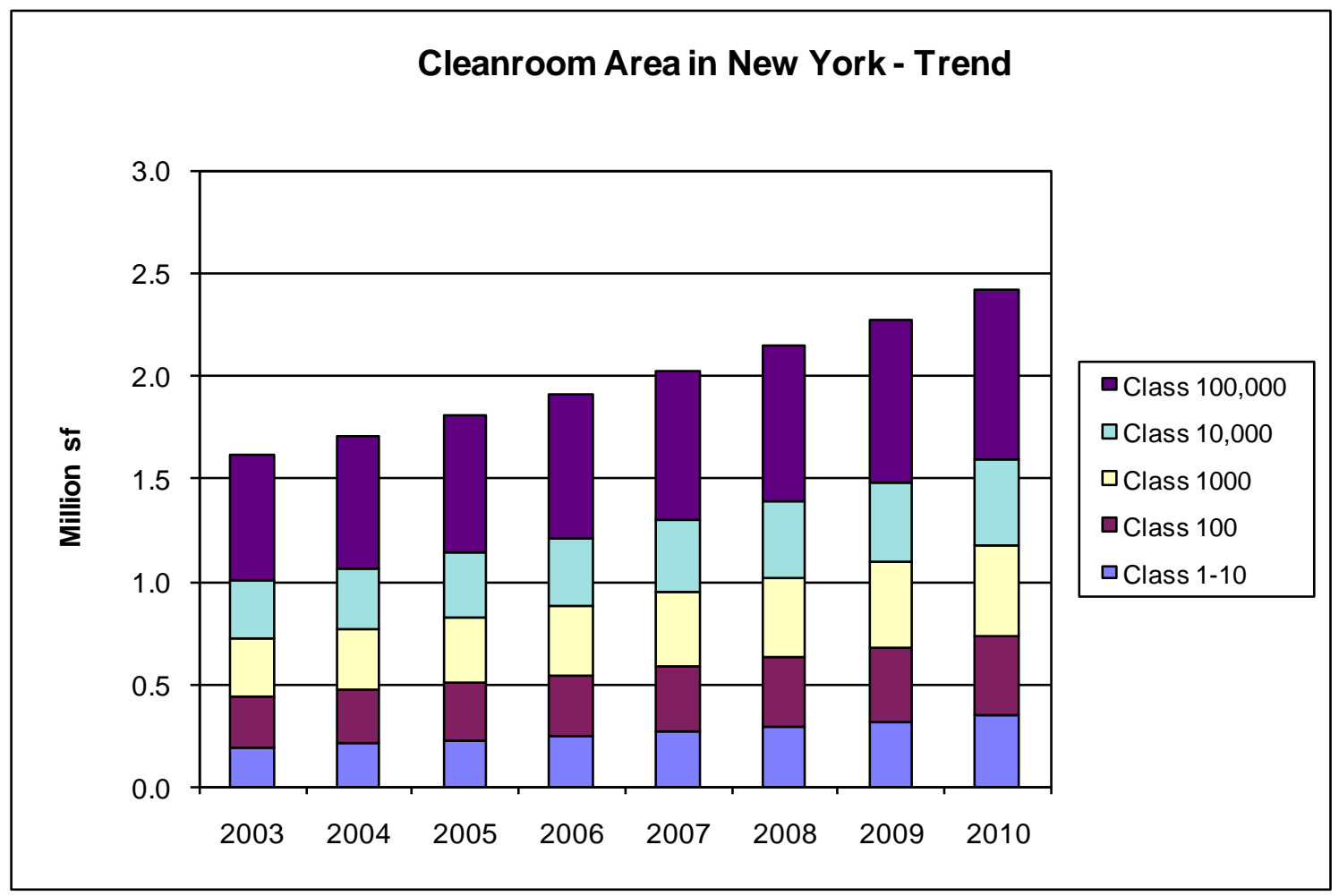

Figure 2 Cleanroom area in New York. Data for 2007-2010 are projected. Data source: McIlvane company. 


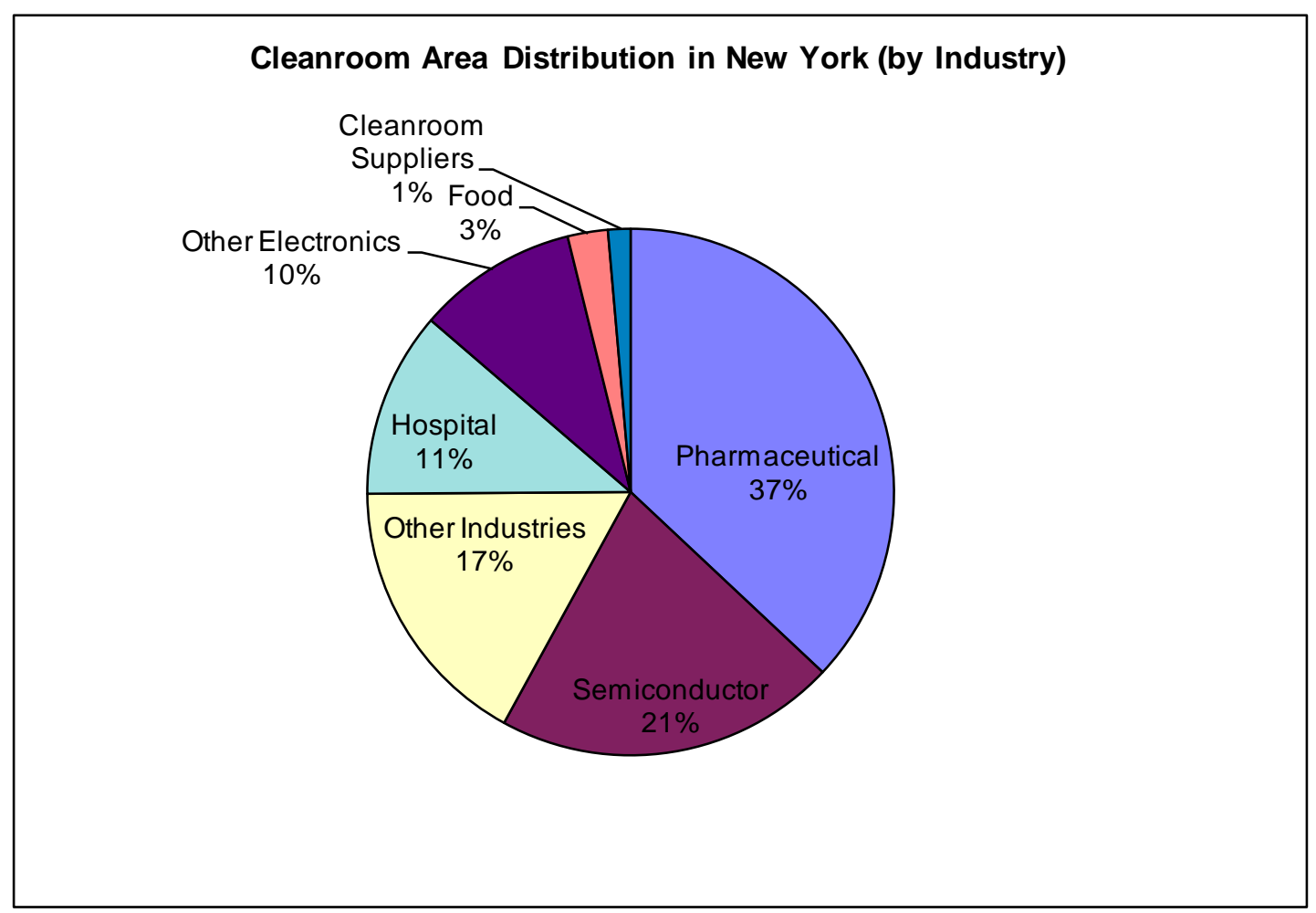

Figure 3. Cleanroom area distribution in New York, by industry type. Data are for 2006. Data source: Mcllvane company.

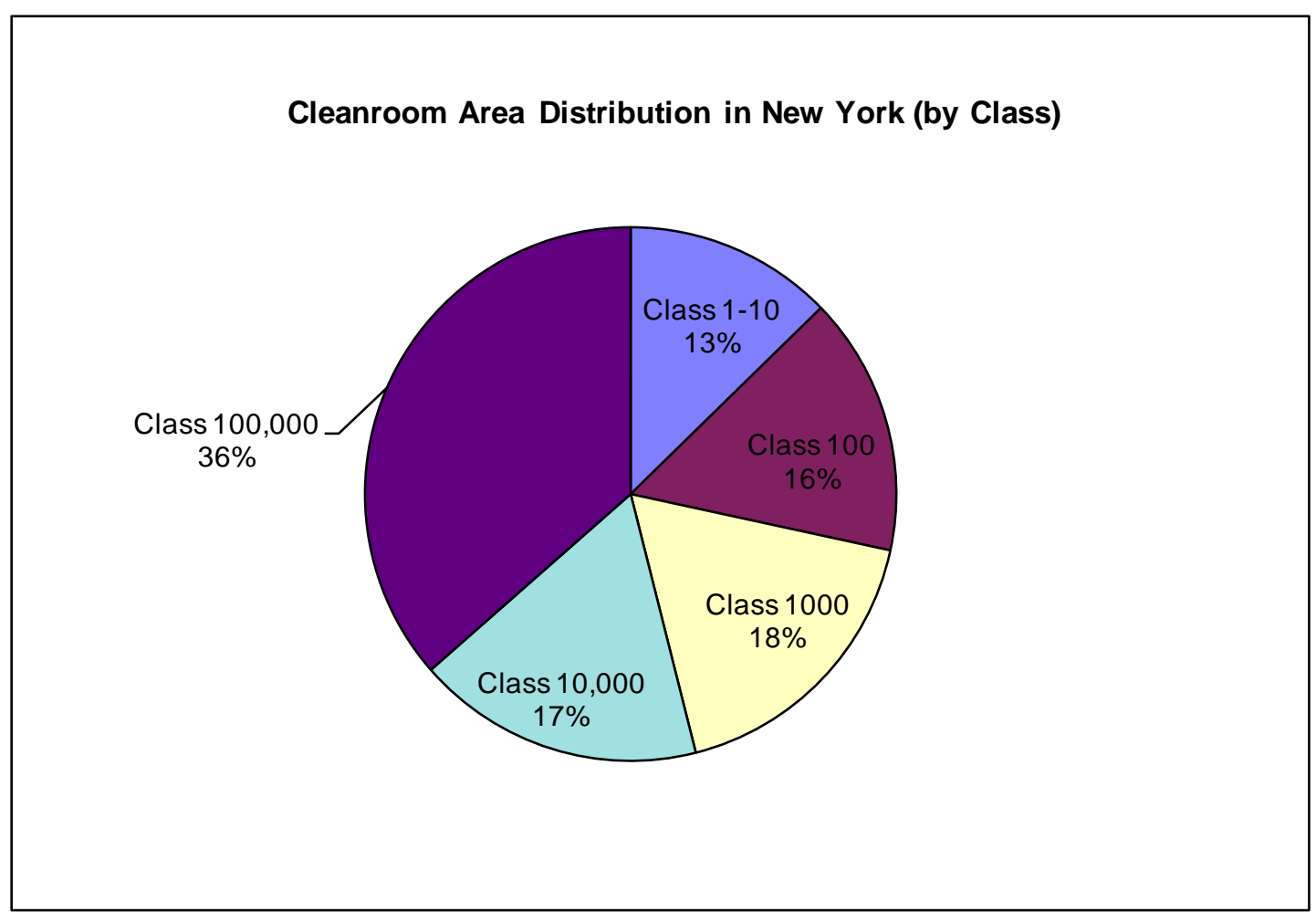

Figure 4. Cleanroom area distribution in New York, by cleanroom class. Data are for 2006. Data source: McIlvane company. 
With sponsorship from the California Energy Commission (CEC), LBNL conducted benchmarking studies for several cleanrooms in California. Figure 5 shows the total measured electrical energy intensity for five cleanrooms for which these data were available. Separately, LBNL also developed bottom -up engineering estimates of cleanroom energy intensity for various classes of cleanrooms, by calculating fan energy, cooling, and heating energy [Mills et al. 1996]. These data were updated for this analysis, and the results (Figure 6) show these engineering estimates are generally within the same range as the measured data in figure 5. There is good agreement between the average intensity in both these data sets. The engineering estimates show somewhat a wider range, which is reasonable considering that it has a wider range of cleanliness classes.

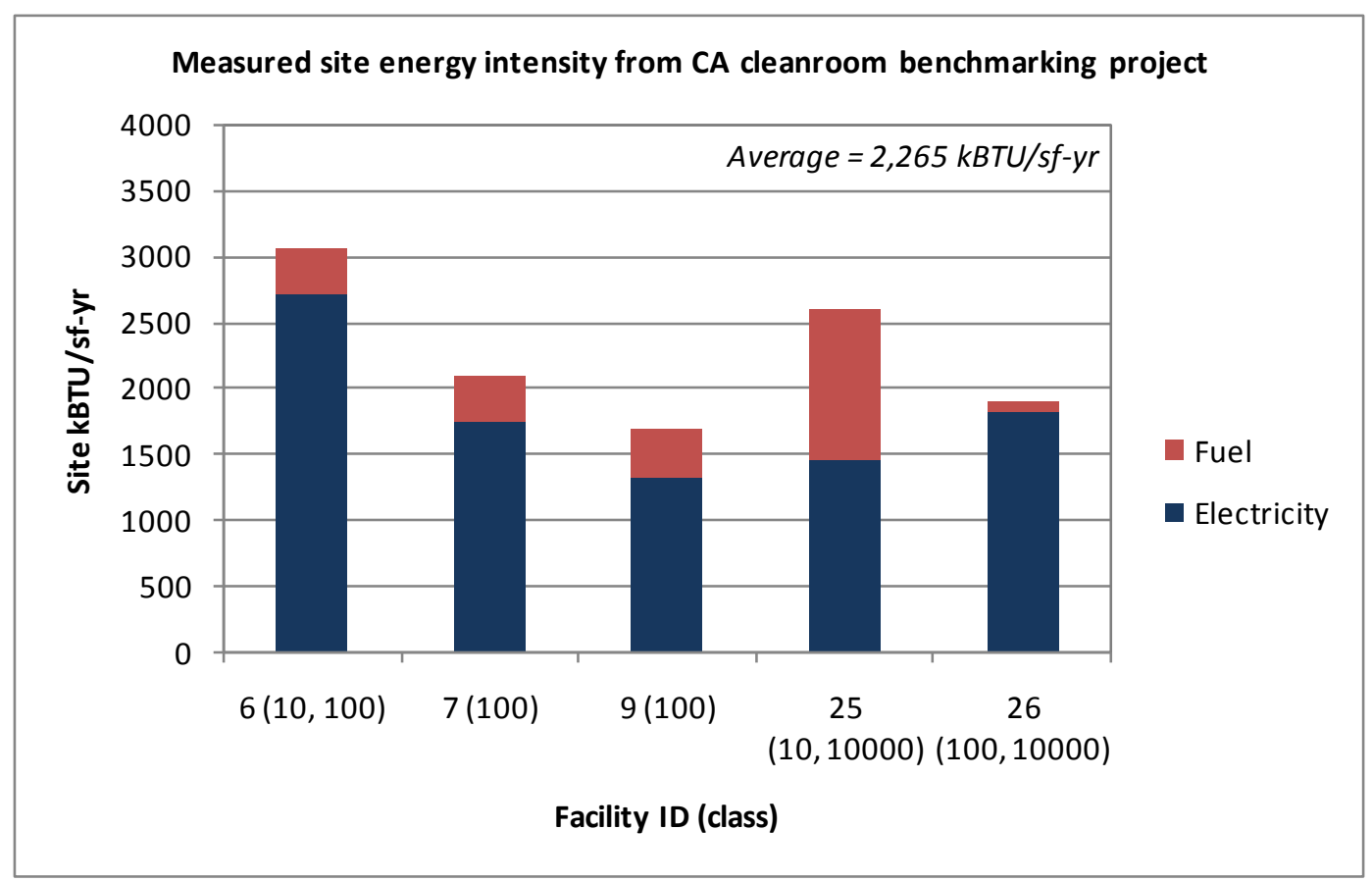

Figure 5. Measured electricity intensity from cleanrooms benchmarked in California. Note that facilities 6,25,26 have multiple clean rooms with different classes.

Data source: $L B N L$ cleanroom benchmarking database 


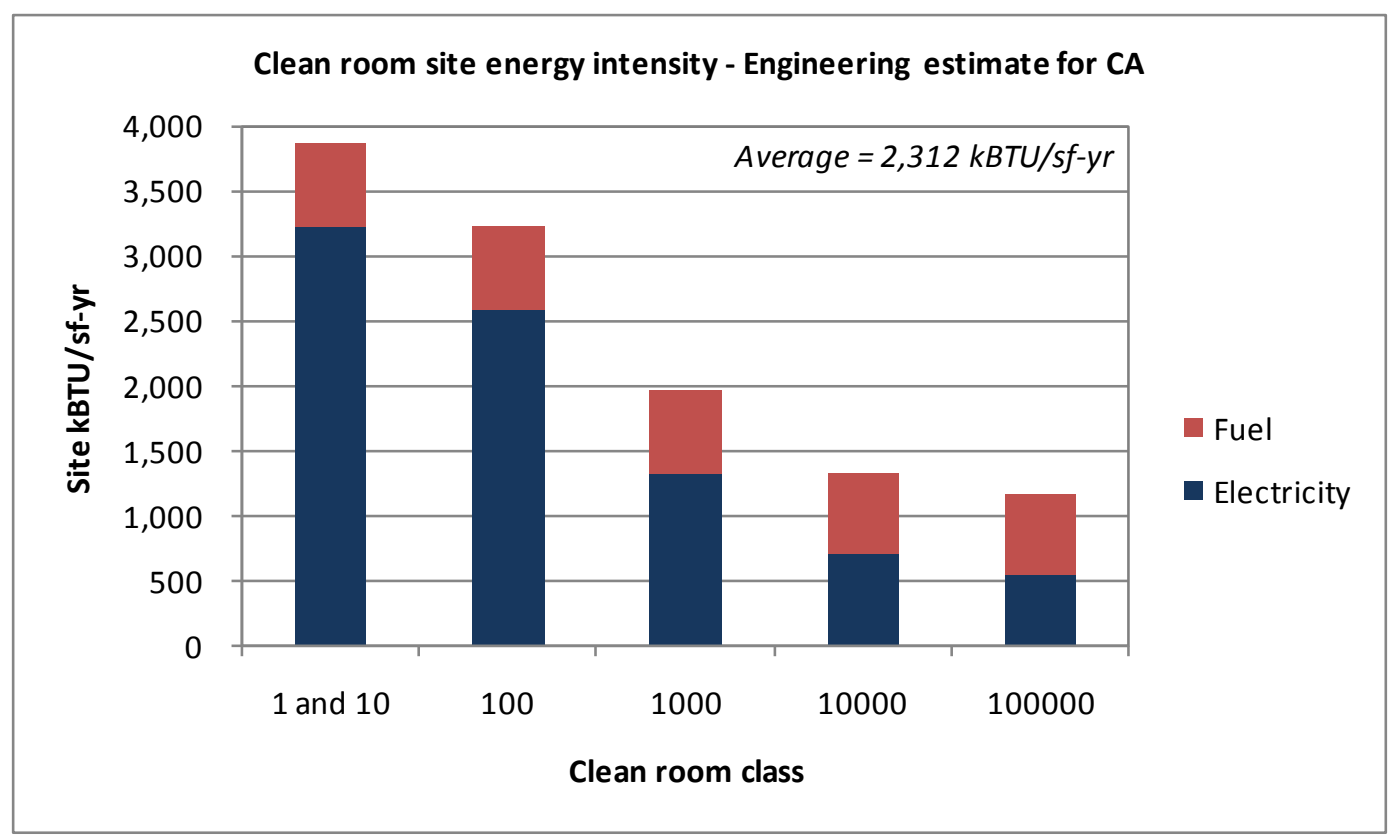

Figure 6. Engineering estimates of cleanroom HVAC electricity intensity, based on Mills et al. [1996].

\subsection{Analysis}

Given the above two sources of data, the approach used to estimate total cleanroom sector energy use was to multiply the floor area data from the Mcllvane report with the energy intensity data from California benchmarking studies. Engineering estimates of energy intensity were used, because they provided class-specific values, which were not available in the measured data. The cooling and heating energy intensity values were normalized using the cooling degree days and heating degree days respectively. Almost all of the fan energy use is in recirculation fan energy, which is not weather dependent. Fan energy varies by cleanroom class, whereas heating and cooling is the same for all classes, assuming that thermal loads are not driven by cleanroom class. Table 5 summarizes the estimation of cleanroom energy use for New York using the above data sources and analysis method. It shows that the total electricity use and expenditures in New York are $696 \mathrm{GWh}$ and $\$ 95$ million. Total fuel energy u se and expenditures are 2.6 trillion BTUs and $\$ 32$ million. Total site energy use and expenditures are 5 trillion BTU s and \$126 million. 


\begin{tabular}{|c|c|c|c|c|c|c|c|c|}
\hline \multirow[b]{2}{*}{ ID } & \multirow[b]{2}{*}{ Clean room Metrics/Data } & \multicolumn{5}{|c|}{ Cleanroom class } & \multirow{2}{*}{$\begin{array}{l}\text { Average } \\
\text { or Total }\end{array}$} & \multirow[b]{2}{*}{ Source/Notes } \\
\hline & & 1 and 10 & 100 & 1000 & 10000 & 100000 & & \\
\hline A & Fan intensity (kWh/sf-yr) & 832 & 647 & 277 & 92 & 46 & 379 & note 1 \\
\hline $\mathrm{B}$ & CA cooling intensity (kWh/sf-yr) & 113 & 113 & 113 & 113 & 113 & 113 & note 1 \\
\hline $\mathrm{C}$ & NY cooling intensity (kWh/sf-yr) & 76 & 76 & 76 & 76 & 76 & 76 & note 2 \\
\hline $\mathrm{D}$ & CA heating intensity (kBTU/sf-yr) & 634 & 634 & 634 & 634 & 634 & 634 & note 1 \\
\hline $\mathrm{E}$ & NY heating intensity (kBTU/sf-yr) & 1,366 & 1,366 & 1,366 & 1,366 & 1,366 & 1,366 & note 3 \\
\hline $\mathrm{F}$ & NY total electrical intensity (kWh/sf-yr) & 908 & 723 & 353 & 168 & 122 & 455 & $A+C$ \\
\hline $\mathrm{G}$ & NY total site intensity (kBTU/sf-yr) & 4,465 & 3,834 & 2,572 & 1,940 & 1,783 & 2,919 & $F^{\star} 3.412+E$ \\
\hline $\mathrm{H}$ & NY Area (million sf) & 0.242 & 0.300 & 0.337 & 0.332 & 0.695 & 1.906 & Mcllvane report \\
\hline 1 & NY Electricity use (GWh) & 219 & 217 & 119 & 56 & 85 & 696 & $\mathrm{H}^{*} \mathrm{~F}$ \\
\hline $\mathrm{J}$ & NY Electricity expenditures (Million \$) & 30 & 29 & 16 & 8 & 12 & 95 & $\$ 0.136 / \mathrm{kWh}$ \\
\hline $\mathrm{K}$ & NY Fuel use (tBTU) & 0.33 & 0.41 & 0.46 & 0.45 & 0.95 & 2.60 & $E * H / 1000$ \\
\hline $\mathrm{L}$ & NY Fuel expenditures (Million \$) & 4 & 5 & 6 & 5 & 11 & 32 & $\$ 12.10 / \mathrm{MCF}$ \\
\hline $\mathrm{M}$ & NY Site energy use (tBTU) & 1.08 & 1.15 & 0.87 & 0.64 & 1.24 & 5 & $\mathrm{G}^{*} \mathrm{H} / 1000$, note 4 \\
\hline $\mathrm{N}$ & NY Site energy expenditures (Million \$) & 34 & 34 & 22 & 13 & 23 & 126 & $\mathrm{~J}+\mathrm{L}$, note 4 \\
\hline & $\begin{array}{l}\text { Notes: } \\
\text { 1. From Mills et al. [1996], with modified assu } \\
\text { 2. Interpolated from CA data, using } 2006 \text { coo } \\
\text { 3. Interpolated from CA data, using } 2005 / 200 \\
\text { 4. Site energy use and expenditures may not }\end{array}$ & $\begin{array}{l}\text { tions for plar } \\
\text { degree days } \\
\text { eating degre } \\
\text { ual sum of el }\end{array}$ & $\begin{array}{l}\text { efficiency } \\
\text { CA CDD = } \\
\text { days. CA H } \\
\text { tricity and }\end{array}$ & $\begin{array}{l}94, N Y \text { CD } \\
=2508, N \\
\text {, due to ro }\end{array}$ & $\begin{array}{l}=797 \\
\text { HDD }=54 \\
\text { ding }\end{array}$ & & & \\
\hline
\end{tabular}

Table 5. Estimate of cleanroom energy use in New York.

\section{Data Centers}

\subsection{Data Sources}

The U.S. EPA Energy Star program has published a report that assesses current trends in energy use and energy costs of data centers and servers in the U.S. and outlines existing and emerging opportunities for improved energy efficiency [EPA 2007]. This report, while being the most comprehensive publicly available report on data center energy use in the U.S., does not have state-level data. A literature search and communications with data center industry experts yielded no other sources of data that could be used to directly estimate the data center market in New York.

\subsection{Analysis}

Given the limitations of existing data sources, the only viable option was to extrapolate the U.S. data to New York i.e. calculate ratio of US data center energy use to US commercial sector use and apply this ratio to New York commercial sector energy use (which is available in the NYSEP report). Table 6 summarizes the analysis. It shows that the total data center electricity use and expenditures in New York are 4,557 GWh and \$ 620 million. Note that most data centers use little if any fuel and therefore the total electricity use is reasonably representative of total site energy use.

\begin{tabular}{|c|c|c|c|}
\hline ID & Data Item & Value & Source \\
\hline A & US - All commercial - Site electricity (tWh) & 1,043 & CBECS \\
\hline $\mathrm{B}$ & US - Data centers - Site electricity (tWh) & 61 & EPA report \\
\hline $\mathrm{C}$ & US - Data centers vs. All (\% site electricity) & $5.9 \%$ & $\mathrm{~B} / \mathrm{A}$ \\
\hline $\mathrm{D}$ & NY - All commercial - Site electricity (GWh) & 77,419 & NYSEP \\
\hline $\mathrm{E}$ & NY - Data centers - Site electricity (GWh) & 4,557 & $C^{*} \mathrm{D}$ \\
\hline $\mathrm{F}$ & NY - Average commercial electricity cost ( $\$ / \mathrm{kWh})$ & 0.136 & NYSEP \\
\hline $\mathrm{G}$ & NY - Data Centers - Electricty expenditures (Million \$) & 620 & $E^{*} \mathrm{~F}$ \\
\hline
\end{tabular}

Table 6. Estimate of data center energy use in New York. 


\section{Summary}

The results for each building type are summarized below in table 7 and figure 7 . It show s that the high tech sector collectively uses about $7.7 \%$ of total site energy used by commercial buildings in New York, and about $11.2 \%$ and $5.6 \%$ of electricity and fuel respectively. The energy expenditures by the high tech sector constitute about $8.7 \%$ of total energy expenditures for the commercial sector in New York.

\begin{tabular}{|l|r|r|r|rr|}
\hline & $\begin{array}{c}\text { Electricity } \\
\text { (GWh) }\end{array}$ & \multicolumn{1}{c|}{$\begin{array}{c}\text { Fuel } \\
\text { (tBTU) }\end{array}$} & \multicolumn{2}{|c|}{$\begin{array}{c}\text { Site Energy } \\
\text { (tBTU) }\end{array}$} & \multicolumn{2}{c|}{$\begin{array}{c}\text { Energy Costs } \\
\text { (Million \$) }\end{array}$} \\
\hline Laboratories & 3,453 & 21 & 33 & $\$$ & 730 \\
\hline Clean rooms & 696 & 3 & 5 & $\mathbf{5}$ & 126 \\
\hline Data centers & 4,557 & $\mathbf{2 4}$ & $\mathbf{5 4}$ & $\mathbf{\$}$ & $\mathbf{1 , 4 7 6}$ \\
\hline Total & $\mathbf{8 , 7 0 6}$ & & & & \\
\hline $\begin{array}{l}\text { Hightech vs. } \\
\text { all commercial (\%) }\end{array}$ & $11.2 \%$ & $5.6 \%$ & $7.7 \%$ & $8.7 \%$ \\
\hline
\end{tabular}

Table 7. Summary of annual electricity, fuel and site energy use and expenditures for laboratories, cleanrooms, and data centers in New York.

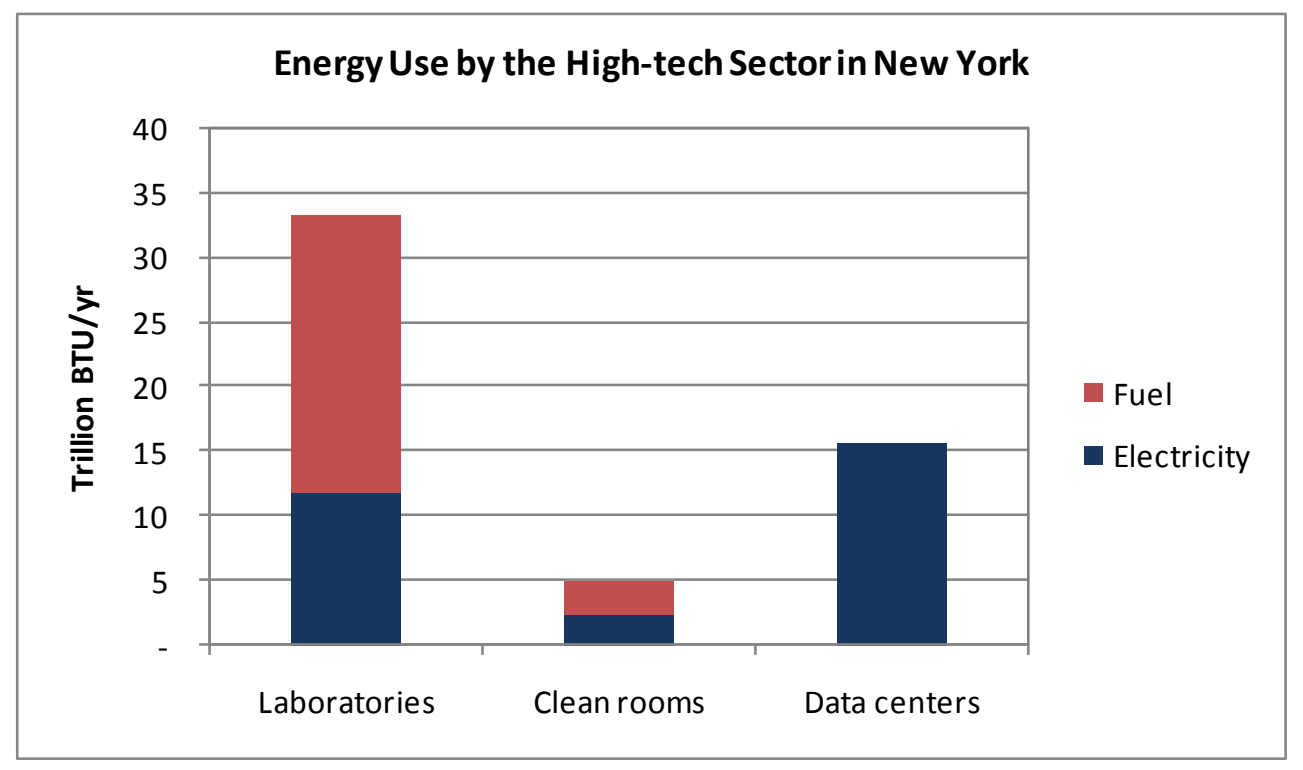

Figure 7. Energy use by laboratories, cleanrooms, and data centers in New York. 


\section{References}

EIA 2003. Commercial Building Energy Consumption Survey, Energy Information Administration, U.S. Department of Energy. Available on the web at: http:/ / www.eia.doe.gov/ emeu/ cbecs/ contents.html

EPA 2007. Report to Congress on Server and Data Center Energy Efficiency, Public Law 109-431. U.S. Environmental Protection Agency ENERGY STAR Program.

Labs21 2008. Labs21 Energy benchmarking tool. Laboratories for the $21^{\text {st }}$ century. Available on the web at: http:/ / labs21.lbl.gov/

Mills, E., G. Bell, D. Sartor, A. Chen, D. Avery, M. Siminovitch, S. Greenberg, G. Marton, A. de Almeida, and L.E. Lock. 1996. "Energy Efficiency in California Laboratory-Type Facilities." Prepared for the California Institute for Energy Efficiency. LBNL-39061. http:/ / eetd.lbl.gov/ emills/ PUBS/ LabEnergy/ LabEnergy.html

NYSERDA 2008. Patterns and Trends. New York State Energy Profiles: 1992-2006. New York State Energy and Research and Development Authority. January 2008. 